\title{
SONETO ACRÓSTICO AL MAESTRO
}

Avellaneda te inculcó el precepto:

"Lo que es posta se muestra aunque no se hable".

Buscaste así la cifra en lo inefable:

"El concepto caballo es un concepto".

Reinventaste la trama del lenguaje.

Tarski, Frege, Quine, Davidson quisieron

Oirte entretejerlos y dijeron:

“iMaestro!” en filosófico homenaje.

Ocurre que ahora sos nuestra leyenda.

Rey Mago de SADAF, Príncipe Azul,

Es belleza analítica tu ofrenda,

Tesoro nuestro en el mejor baúl.

Tu huella seguiremos por la senda

Inquieta de Tomás y de Raúl.

Federico Penelas 